\title{
GBV-C/HGV and HIV-1 Coinfection
}

\author{
Maria Teresa Maidana ${ }^{1}$, Ester Cerdeira Sabino ${ }^{2}$ \\ and Esper Georges Kallas ${ }^{1}$
}

Federal University of São Paulo ${ }^{1}$; Pró-Sangue

Foundation'; São Paulo, SP, Brazil

\begin{abstract}
An interesting interaction pattern has been found between HIV-1 and GBV-C/HGV, resulting in protection against progression to AIDS. The mechanisms involved in this interaction remain to be clarified. We examined the current knowledge concerning this coinfection and developed hypotheses to explain its effects. A better understanding of this interaction could result in new concepts, which may lead to new strategies to control HIV-1 replication and progression to AIDS. Key Words: HIV, HGV, GBV-C, pathogenesis, review
\end{abstract}

Patients infected with the human immunodeficiency virus (HIV) are often co-infected with other pathogens, especially hepatitis viruses [1]. Coinfection with hepatitis $\mathrm{B}$ virus (HBV) or hepatitis $\mathrm{C}$ virus (HCV) appears to increase the mortality rate among HIV-infected patients [2], in the same way as the course of HCV infection is accelerated in patients who are coinfected with HIV, when compared with immunocompetent individuals $[3,4]$. A new virus related to hepatitis $C$ virus was identified in 1995; it was initially thought to be another hepatitis agent [5,6]. It has been described as either GB virus $\mathrm{C}(\mathrm{GBV}-\mathrm{C})$ [5] or hepatitis $\mathrm{G}$ virus (HGV) [6]. GBV-C and HGV are closely related, with more than 95 percent sequence homology [7]. The name GBV-C has been more widely used, since it appears that this virus is not a causative agent of hepatitis $[7,8]$.

GB virus C (GBV-C), an RNA virus in the Flaviviridae family, has a genome very similar to that of hepatitis $\mathrm{C}$ virus (HCV), coding for structural and nonstructural proteins. There is a nontranslated region (NTR) at 5' that can serve as an internal ribosomal entry site to direct translation of the uncapped message

Received on 17 Dezember 2004; revised 30 March 2005.

Address for correspondence: Dr. Esper Georges Kallas, M.D., Ph.D. Laboratório de Imunologia, Disciplina de Doenças Infecciosas e Parasitárias. Escola Paulista de Medicina / UNIFESP. Rua Pedro de Toledo 781, $15^{\circ}$ andar, Zip code: 04039032 - São Paulo - SP, Brazil. E-mail: kallas.dmed@epm.br

The Brazilian Journal of Infectious Diseases 2005;9(2):122-125 (C) 2005 by The Brazilian Journal of Infectious Diseases and Contexto Publishing. All rights reserved. (genome) RNA [9]. GVB-C appears to encode two structural glycoproteins, which constitute the virus envelope proteins E1 and E2. However, the precise composition of the nucleocapsid has yet to be defined. To date, five genotypes of HGV have been described, with 12 percent divergence between them [10,11]. Genotype 1 is predominant in West Africa, genotype 2 in Europe and the USA, genotype 3 in Asia, genotype 4 in Southeast Asia and genotype 5 in South Africa [12]. In Brazil, two reports have described the genotype distribution. Oliveira et al. evaluated 17 GVB-C-infected blood donors using RFLP, of which $10(59 \%)$ were infected by genotype $2 \mathrm{~b}$, four infected by genotype $2 \mathrm{a}(24 \%)$, and three by genotype 1 (18\%) [13]. Nishiya et al. screened over 1,000 healthy subjects, and analyzed 24 GVB-C-infected patients, using RT-PCR followed by genome sequencing; they found 12 subjects infected by genotype $2 \mathrm{a}(50 \%), 10$ by genotype $2 \mathrm{~b}(42 \%)$, and two by genotype $1(8.3 \%)$ [14].

Although many people are infected with this virus throughout the world, no clear association with a known disease state has been demonstrated. GBV-C is transmitted predominantly through parenteral routes, with a high seroprevalence among intravenous illicit drug users, although sexual transmission has also been reported [15].

Based on the very low density of the virus particles, it appears that GBV-C associates with lipids in human serum, and like $\mathrm{HCV}$, it may use the low density 
lipoprotein receptor for virus binding and entry into target cells [16]. Virus derived from an infectious molecular clone can replicate in $\mathrm{CD}_{4}^{+}$cells in peripheral blood mononuclear cell (PBMC) cultures [17].

GBV-C clearance is common in immunocompetent subjects, occurring in approximately 60 to $75 \%$ of GBV-C-infected persons, along with the development of antibodies against the envelope glycoprotein E2 [18]. GBV-C infection has not been associated with any known disease and does not appear to represent a substantial threat to public health. For this reason, the Food and Drug Administration (FDA) has not recommended screening blood donors for GBV-C RNA, although this persistent infection is common, present in approximately $1.8 \%$ of American donors and more than $35 \%$ of the HIV-infected subjects [19]. In Brazil, the prevalence of $\mathrm{HGV}$ in blood donors is higher, being around 9\% [20]. In a study conducted in a representative sample of the city of São Paulo, it was found that the prevalence varies according to the age group, peaking in individuals between 30 and 40 years old. The prevalence in children between 5 and 9 years old was found to be high (2.9\%), suggesting that other transmission routes, besides parenteral and sexual, are important in this age group [21].

Whereas the presence of antibodies against the envelope protein E2 (anti-E2) indicates viral clearance, the presence of GBV-C RNA in serum or plasma indicates ongoing GBV-C infection [22]. GBV-CRNA can be detected by nucleic acid amplification systems [23-25], and quantification has been accomplished using branched chain DNA assays [26] and real-time (Taq Man) polymerase chain reaction (PCR).

GBV-C viremia is associated with a lower mortality rate among HIV-1 infected patients, slower progression to AIDS, and longer survival once AIDS has developed [26-29]. In another study, these effects were found to be independent of age, HIV-1 load, $\mathrm{HCV}$ load, $\mathrm{CD}_{4}^{+}$ and $\mathrm{CD}_{8}{ }^{+} \mathrm{T}$ cell counts, and $\mathrm{CC}$ chemokine receptor 5 (CCR5) genotype [30]. It was also observed that serum levels of interleukin-2 (IL-2), IL-12, IL-4, and IL-10 remained relatively stable over time in the GBVC RNA-positive group, while the GBV-C RNA negative group had a decrease in IL-2 and IL-12 of approximately $85 \%$ and $83 \%$, respectively, and IL-4 and IL-10 increased by 654 and 395\%, respectively, preserving a TH1 cytokine response [29].

GBV-C virus did not prevent the entry of HIV in the cell or the depletion of $\mathrm{TCD}_{4}^{+}$cells, but it did have an inhibitory effect in replication and HIV growth in cell culture [31]. This effect did not appear to be a result of cellular toxicity, considering that GBV-C replication in peripheral-blood mononuclear cells appeared to be noncytopathic and did not inhibit the synthesis of cellular proteins [31].

Over the past several years, there has been substantial controversy over the interactions between GBV-C and HIV in vivo. A number of studies have demonstrated a surprising survival benefit among patients who are coinfected, when compared with those who are only infected with HIV-1. Other studies, however, have not shown such effects. The article by Williams et al. [32] may settle a few aspects of this controversy, since it clearly demonstrates that five to six years after HIV-1 seroconversion patients were more likely to be dead if they were infected only with HIV-1 than if they were coinfected with both HIV-1 and GBV-C. This significant survival advantage was not observed during the first 12 to 18 months after HIV-1 seroconversion. Likewise, the time dependence could explain the contradictory results of some studies regarding the observed protective effects of GBV-C [32].

As further evidence of the protective effect of dual infections, Williams et al. also found that the course of HIV-1 disease was adversely affected by the clearance of GBV-C viremia [32]. The mechanism of this protective effect remains to be determined and there are a number of possibilities to explain it.

In addition, some studies suggest that HIV-1 replication is directly reduced by GBV-C. The fact that both HIV-1 and GBV-C can infect and replicate within peripheral-blood mononuclear cells suggests that these two viruses interact either directly or indirectly throughout the cell cycle. Various stages of the HIV life cycle may be affected by GBV-C, including retroviral binding and fusion to target cells through the high-affinity receptor and several chemokine 
coreceptors, internalization and reverse transcription, integration into the host-cell genome to create the HIV provirus, viral transcription, translation and viral morphogenesis; another possibility is a series of interactions that involve CCR5.

The level of CCR5 expression is an important factor for HIV transmission and disease progression [33]. It was observed that the envelope glycoproteins of GBV$\mathrm{C}$, specifically $\mathrm{E} 2$, bind to $\mathrm{CD}_{81}$ on T lymphocytes. This interaction induces a dose-dependent secretion of RANTES, a natural ligand of CCR5, which induces internalization of CCR5 and down-regulation of CCR5 surface expression, with concomitant intracellular accumulation of CCR5 proteins on $\mathrm{CD}_{4}^{+}$and $\mathrm{CD}_{8}^{+} \mathrm{T}$ lymphocytes of $\mathrm{HGV}$-infected subjects, at a rate of 53 and $36 \%$, respectively. Hence, the internalization of chemokine receptors is an effective mechanism to block cellular entry of HIV into the cells [34,35]. However, it remains unclear why HGV E2 specifically induces RANTES, but not MIP-1 $1 \alpha$ or MIP-1 $\beta$, which are other ligands of CCR5 [36]. On the other hand, it would be of interest to know whether GBV-C clearance is associated with HIV-mediated destruction of host cells necessary for the production of GBV-C, preceding the loss of $\mathrm{CD}_{4}^{+} \mathrm{T}$ cells.

There is a long history of interactions between different viruses; in most cases one virus increases the pathogenicity of the other. The interaction between HIV-1 and GBV-C is unusual and curious, and it is beneficial to patients who are dually infected. It is, therefore, of great interest to understand the mechanisms involved in this interaction, because it could result in progress in our understanding of viral pathogenesis and in a contribution towards the development of novel HIV-1 treatment strategies.

\section{References}

1. McNair A.N., Main J., Thomas H.C. Interactions of the human immunodeficiency virus and the hepatotropic viruses. Semin Liver Dis 1992; 12:188-96.

2. Ockenga J., Tillmann H.L., Trautwein C., et al. Hepatitis B and $\mathrm{C}$ in $\mathrm{HIV}$-infected patients: prevalence and prognostic value. J Hepatol 1997;27:18-24.
3. Fischer H.P., Willsch E., Bierhoff E., Pfeifer U. Histopathologic findings in chronic hepatitis C. J Hepatol 1996;24:Suppl:35-42.

4. Pol S., Fontaine H., Carnot F., et al. Predictive factors for development of cirrhosis in parenterally acquired chronic hepatitis $\mathrm{C}$ : a comparison between immunocompetent and immunocompromised patients. J Hepatol 1998;29:12-9.

5. Simons J.N., Leary T.P., Dawson G.J., et al. Isolation of novel virus-like sequences associated with human hepatitis. Nat Med 1995;1:564-9.

6. Linnen J., Wages J. Jr, Zhang-Keck Z.Y., et al. Molecular cloning and disease association of hepatitis $G$ virus: a transfusion-transmissible agent. Science 1996;271:505-8.

7. Alter H.J. The cloning and clinical implications of $\mathrm{HGV}$ and HGBVC. N Engl J Med 1996;334:1536-7.

8. Tillmann H.L., Heringlake S., Trautwein C., et al. Antibodies against the GB virus $C$ envelope 2 protein before liver transplantation protect against $\mathrm{GB}$ virus $\mathrm{C}$ de novo infection. Hepatology 1998;28:379-84.

9. Simons J.N., Desai S.M., Schultz D.E., et al. Translation initiation in GB viruses $A$ and $C$ : evidence for internal ribosome entry and implications for genomic organization. J Virol 1996;70:6126-35.

10. Okamoto H., Nakao H., Inoue T., et al. The entire nucleotide sequences of two $\mathrm{GB}$ virus $\mathrm{C} /$ hepatitis $\mathrm{G}$ virus isolates of distinct genotypes from Japan. J Gen Virol 1997;78(4):737-45.

11. Tucker T.J., Smuts H., Eickhaus P., et al. Molecular characterization of the 5' non-coding region of South African GBV-C/HGV isolates: major deletion and evidence for a fourth genotype. J Med Virol 1999;59(1):52-9.

12. Tucker T.J., Smuts H.E. GBV-C/HGV genotypes: proposed nomenclature for genotypes 1-5. J Med Virol 2000;62(1):82-3.

13. Oliveira L.A., Martins R.M., Carneiro M.A., et al. Prevalence and genotypes of GB virus $\mathrm{C} /$ hepatitis $\mathrm{G}$ virus among blood donors in Central Brazil. Mem Inst Oswaldo Cruz. 2002 ;97(7):953-7.

14. Nishiya A.S., Ribeiro-dos-Santos G., Bassit L., et al. Genotype distribution of the GB virus $\mathrm{C}$ in citizens of Sao Paulo City, Brazil. Rev Inst Med Trop Sao Paulo 2003;45(4):213-6.

15. Frey S.E., Homan S.M., Sokol-Anderson M., et al. Evidence for probable sexual transmission of the hepatitis $G$ virus. Clin Infect Dis 2002;34(8):1033-8.

16. Xiang J., Klinzman D., McLinden J., et al. Characterization of hepatitis $\mathrm{G}$ virus (GB-C virus) particles: evidence for a nucleocapsid and expression of sequences upstream of the E1 protein. J Virol 1998;72:2738-44. 
17. Xiang J., Wunschmann S., Schmidt W.N., et al. Fulllength GB virus $\mathrm{C}$ (hepatitis $\mathrm{G}$ virus) RNA transcripts are infectious in primary CD4-positive T cells. J Virol 2000;74:9125-33.

18. Thomas D.L., Vlahov D., Alter H.J., et al. Association of antibody to $\mathrm{GB}$ virus $\mathrm{C}$ (hepatitis $\mathrm{G}$ virus) with viral clearance and protection from reinfection. J Infect Dis 1998; $177: 539-42$.

19. Dawson G.J., Schlauder G.G., Pilot-Matias T.J., et al. Prevalence studies of GB virus-C infection using reverse transcriptase-polymerase chain reaction. J Med Virol 1996;50:97-103.

20. Bassit L., Kleter B., Ribeiro dos Santos G., et al. Hepatitis $\mathrm{G}$ virus: prevalence and sequence in blood donors of São Paulo, Brazil. Vox Sanguinis 1998;74:83-7.

21. Ribeiro-dos-Santos G., Nishiya A.S., Nascimento C.M., et al. Prevalence of GB virus $C$ (hepatitis $G$ virus) and risk factors for infection in Sao Paulo, Brazil. Eur J Clin Microbiol Infect Dis 2002;21(6):438-43.

22. Dille B.J., Surowy T.K., Gutierrez R.A., et al. An ELISA for detection of antibodies to the $\mathrm{E} 2$ protein of $\mathrm{GB}$ virus $\mathrm{C}$. J Infect Dis 1997; 175:458-61.

23. Linnen J., Wages J., Zhang-Keck Z.-Y., et al. Molecular cloning and disease association of hepatitis $G$ virus: A transfusion-transmissible agent. Science 1996;271:505-8.

24. Simons J.N., Leary T.P., Dawson G.J., et al. Isolation of novel virus-like sequences associated with human hepatitis. Nat Med 1995; 1:564-9.

25. Dawson G.J., Schlauder G.G., Pilot-Matias T.J., et al. Prevalence studies of GB virus-C using reversetranscriptase polymerase chain reaction. J Med Virol 1996;50:97-103.

26. Tillmann H.L., Heiken H., Knapik-Botor A., et al. Infection with GB virus $\mathrm{C}$ and reduced mortality among HIVinfected patients. N Engl J Med 2001;345:715-24.

27. Heringlake S., Ockenga J., Tillmann H.L. GB virus C/ hepatitis $G$ virus infection: a favorable prognostic factor in human immunodeficiency virus-infected patients? J Infect Dis 1998; 177:1723-6.

28. Rodriguez B., Valdez H., Lederman M.M. Effect of hepatitis $\mathrm{G}$ co-infection on response to antiretroviral treatment in HIV-infected patients. Presented at the $39^{\text {th }}$ Infectious Diseases Society of America Meeting. 2001; San Francisco, CA. Abstract 698.

29. Nunnari G., Nigro L., Palermo F., et al. Slower progression of $\mathrm{HIV}$-1-infection in $\mathrm{HGV} / \mathrm{GB}$ virus $\mathrm{C}$ co-infected individuals correlates with an intact $\mathrm{T}$ helper 1 cytokine profile. Presented at the Retrovirus Conference. 2002; Seattle, WA .

30. Yeo A.E.T., Matsumoto A., Hisada M., et al. Effect of hepatitis $\mathrm{G}$ virus infection on progression of $\mathrm{HIV}$ infection in patients with hemophilia: Multicenter Hemophilia Cohort Study. Ann Intern Med 2000;132:959-63.
31. Xiang J.I., Wünschmann S.A., Diekema D.J., et al. Effect of coinfection with GB virus on survival among patients with HIV infection. N Engl J Med 2001;345(10):707-14 .

32. Williams C.F., Klinzman D.B.A., Yamashita T.E., et al. Persistent GB Virus C Infection and Survival in HIVInfected Men. N Engl J Med 2004;350(10):981-90.

33. Cocchi F., DeVico A.L., Yarchoan R., et al. Higher macrophage inflammatory protein (MIP)-1alpha and MIP-1beta levels from $\mathrm{CD}_{8}^{+} \mathrm{T}$ cells are associated with asymptomatic HIV-1 infection. Proc Natl Acad Sci USA 2000,97:13812-7.

34. Brandt S.M., Mariani R., Holland A.U., et al. Association of chemokine-mediated block to HIV entry with coreceptor internalization. J Biol Chem 2002;277:17291-9.

35. Alkhatib G., Locati M., Kennedy P.E., et al. HIV-1 coreceptor activity of CCR5 and its inhibition by chemokines: independence from $\mathrm{G}$ protein signaling and importance of coreceptor downmodulation. Virology 1997;234:340-8.

36. Nattermann J., Nischalke H.D., Kupfera B.,et al. Regulation of $\mathrm{CC}$ chemokine receptor 5 in Hepatitis $\mathrm{G}$ virus infection. AIDS 2003; 17(10):1457-62. 